\title{
Modification by propylene glycol of ovulation rate in ewes in response to a single injection of FSH
}

\author{
A. Lopez-Sebastian ${ }^{1}$, A. Gomez-Brunet ${ }^{1}$, A. W. Lishman ${ }^{2}$, \\ S. K. Johnson ${ }^{3}$ and E. K. Inskeep ${ }^{3}$ \\ ${ }^{1}$ Departamento de Produccion Animal, Instituto Nacional de Investigaciones Agrarias, Centro de \\ Investigación y Tecnología, 28080, Madrid, Spain; ${ }^{2}$ Department of Animal Science, University of \\ Natal, Pietermaritzburg, 3200 Natal, South Africa; and ${ }^{3}$ Division of Animal Science, West Virginia \\ University, Morgantown, WV 26506-6108, USA
}

\begin{abstract}
Five experiments were conducted with the objective of developing a method to induce superovulation in ewes with a single i.m. injection of FSH. This was achieved by injection of $10 \mathrm{mg}$ FSH-P in propylene glycol at the same time as luteolysis was induced by cloprostenol on day 13 of the oestrous cycle (day $0=$ oestrus). Experiments 1, 2, 3 and 5 were conducted in a single flock of Manchega ewes in Spain during the breeding season. Ovulation rates were determined at laparoscopy. In Expt 1, FSH-P was diluted in saline, and neither $5 \mathrm{mg}$ FSH on day 1 nor 5 or $10 \mathrm{mg} \mathrm{FSH}-\mathrm{P}$ on day 13 changed the ovulation rate after cloprostenol treatment on day 13. In Expt 2, FSH-P was diluted in propylene glycol and data were collected over 2 years. Ten milligrams FSH-P, on day 13 only, increased $(P<0.01)$ the mean number of corpora lutea to 5.5 compared with a control value of 1.5. Five milligrams FSH-P on day 13 only had no effect; however, $5 \mathrm{mg}$ FSH-P on day 1 reduced the mean number of corpora lutea formed in ewes receiving $10 \mathrm{mg}$ FSH-P on day 13 to $2.6(P<0.01)$. Saline and propylene glycol, as vehicles for $10 \mathrm{mg}$ FSH-P, were compared directly at two times of injection in Expt 3. FSH-P increased the mean number of corpora lutea when injected on day 13 in propylene glycol $(4.7)$ but not in saline $(2.5 ; P<0.5)$. Ovulation rate did not differ between diluents when FSH-P was injected $24 \mathrm{~h}$ before cloprostenol (1.3; day 12). Experiments 4 and 5 were conducted to examine possible mechanisms by which propylene glycol improved the response to FSH. In Expt 4, conducted during anoestrus in a crossbred flock in West Virginia, concentrations of FSH in plasma were measured for $58 \mathrm{~h}$ after injection of $10 \mathrm{mg}$ FSH-P in saline or propylene glycol. Propylene glycol did not delay the time of maximum concentration of FSH in plasma after i.m. injection $(2.7 \pm 0.7 \mathrm{~h})$ when compared with saline injection $(3.6 \pm 0.5 \mathrm{~h}$ ). Maximum concentration was reached later when FSH-P was injected s.c. in propylene glycol $(7.6 \pm 0.7 \mathrm{~h} ; P<0.05)$. In Expt 5 , ovulation rate was greater $(P<0.05)$ in ewes treated with $10 \mathrm{mg}$ FSH-P in propylene glycol than in ewes treated with FSH-P in saline and an injection of propylene glycol at a separate site. The number of corpora lutea did not differ in ewes treated with FSH-P in saline and in ewes treated with FSH-P in saline and propylene glycol at a separate site. Thus neither delayed absorption nor an augmentation effect could account for the benefit of propylene glycol as a vehicle for delivery of FSH to superovulate ewes.
\end{abstract}

\section{Introduction}

One of the most important objectives in improvement of reproductive performance in sheep is to increase ovulation rate and subsequent prolificacy. Exogenous gonadotrophins have been used for this purpose, as early studies showed the effectiveness of follicle-stimulating extracts of the pituitary gland in inducing multiple pregnancies (Casida et al., 1944).
Attempts have been made to correlate patterns of circulating FSH, observed during the oestrous cycle (L'Hermite et al., 1972) with ovulation rate. Cahill et al. (1981) and Lahlou-Kassi et al. (1984) reported higher concentrations of FSH at about the times of both the pro-oestrous peak and the secondary or postovulatory peak, in prolific compared with non-prolific breeds.

Injections of more purified preparations of FSH during the follicular phase are currently used to induce superovulation in ewes (Armstrong and Evans, 1983; Rexroad and Powell, 1991). The use of exogenous FSH shortly after the previous oestrus and ovulation, to recruit growth of new follicles before Downloaded from Bioscientifica.com at 04/26/2023 01:35:12PM
and Fertility Ltd
via free access 
superovulatory treatment, has been studied extensively in cows. Despite considerable variability in response, ovulation rate was increased significantly in some of these experiments (Ware et al., 1988). However, no positive effect of this treatment was observed in ewes (Ware et al., 1988).

A method to increase ovulation rate that is both simple and highly repeatable is needed. Many early studies showed that response to gonadotrophins, as measured by ovarian weight in rats, varied with source of gonadotrophin, route of administration and inclusion of such substrates as metallic hydroxides, haeme, formed elements of the blood, copper salts, yeast or zinc sulfate in the injection vehicle (Fevold et al., 1936; Deanesly, 1939; McShan and Meyer, 1945). The initial objective of this work was to evaluate the effect of a single injection of FSH-P in saline, one day after oestrus or at the beginning of luteolysis induced by cloprostenol, on ovulation rate in cyclic ewes. Owing to the lack of effect, and expected short period of effectiveness of FSH diluted in saline (half-life $110 \mathrm{~min}$; Fry et al., 1987), the experiment was repeated with FSH-P diluted in a vehicle containing propylene glycol. The effects of FSH-P in each vehicle at times of injection relative to cloprostenol were compared in a third experiment. Finally, two experiments were conducted to determine why propylene glycol was a more effective diluent than was saline. In one study, the patterns of concentrations of FSH in plasma were examined after injection of FSH-P in saline or propylene glycol. In the other study, the ability of an independent injection of propylene glycol to potentiate the effects of FSH-P in saline was examined.

\section{Materials and Methods}

Experiments 1, 2, 3 and 5 were conducted in Madrid, Spain, with Manchega ewes from a flock of 120 born in December 1985; the ewes weighed an average of $50 \mathrm{~kg}$ during Expt 1 and approximately $60 \mathrm{~kg}$ during subsequent experiments.

\section{Experiment 1}

In Expt 1, 98 ewes detected to be at oestrus by vasectomized rams during their first breeding season, in November and December 1986, were assigned at random to one of six groups in a $2 \times 3$ factorial arrangement of treatments. On day 1 (day $0=$ oestrus) ewes received a single i.m. injection of either saline ( $n=50$ ) or $5 \mathrm{mg}$ of FSH-P (Schering-Plough, Kenilworth, $\mathrm{NJ})$, diluted in $1 \mathrm{ml}$ of saline $(n=48)$. On day 13 after oestrus, ewes received a single i.m. injection of either $0(n=33), 5$ $(n=33)$ or $10(n=32) \mathrm{mg}$ of FSH-P in saline. On day 13 , coincident with the injection of FSH-P, each ewe was injected i.m. with $100 \mu \mathrm{g}$ cloprostenol (Estrumate, ICI, Berkhamsted). Ewes were observed for oestrus once a day, with the aid of vasectomized rams, for three days after treatment with cloprostenol. Laparoscopic observations of the ovaries were performed 7-12 days after oestrus, to count the number of corpora lutea. There was no evidence of return to oestrus before laparoscopy and no recent ovulations were observed at laparoscopy.

\section{Experiment 2}

Experiment 2 was repeated in the same flock during the breeding seasons of two consecutive years. In November 1987,
48 nonlactating ewes, which had lambed in July-August and from which lambs had been weaned 35 days after lambing, were treated. In 1988, 89 nonlactating ewes, which had lambed in August and early September, were treated in NovemberDecember. The factorial design for dose and day of treatment, the synchronization with cloprostenol and the route of administration of FSH-P were the same as in Expt 1. However, the FSH-P was diluted in propylene glycol (1-2-propanediol; Merck, Schuchardt) as follows: 50 mg FSH-P contained in a vial was first diluted in $2 \mathrm{ml}$ of saline, and $8 \mathrm{ml}$ propylene glycol were added to complete a dilution of FSH-P to $5 \mathrm{mg} \mathrm{ml}^{-1}$ in a $\mathrm{I}: 4 \mathrm{v}: \mathrm{v}$, saline:propylene glycol vehicle.

\section{Experiment 3}

In Expt 3, ewes from the same flock that had lambed in September were used during the breeding season of 19891990. Fifty-nine nonlactating ewes, detected at oestrus in December-January were assigned at random to one of four groups in a $2 \times 2$ factorial arrangement, to compare the effect of vehicle (propylene glycol versus saline), when $10 \mathrm{mg}$ FSH-P were administered i.m. on day 12 or 13 of the oestrous cycle. An i.m. injection of $100 \mu \mathrm{g}$ of cloprostenol was given on day 13 .

\section{Experiment 4}

In Expt 4, the patterns of FSH-P in plasma were determined after treatment with FSH-P diluted in saline or in propylene glycol. Twenty-five adult anoestrous ewes (sired by Suffolk rams from ewes of mixed breeds and weighing $60-70 \mathrm{~kg}$ ) were treated in May, 1989, during the nonbreeding season, at Morgantown, WV. Ewes were assigned at random to one of four groups. Group $1(n=10)$ received an i.m. injection of $10 \mathrm{mg}$ FSH-P in $2 \mathrm{ml}$ of saline; group $2(n=5)$ received $10 \mathrm{mg}$ FSH-P i.m. in $2 \mathrm{ml}$ of propylene glycol; group $3(n=5)$ received $10 \mathrm{mg}$ FSH-P s.c. in $2 \mathrm{ml}$ of propylene glycol; and group $4(n=5)$ served as controls, receiving an i.m. injection of $2 \mathrm{ml}$ of propylene glycol.

Blood samples were taken from the jugular vein from $12 \mathrm{~h}$ before to $58 \mathrm{~h}$ after injection of FSH-P. The sampling schedule was once at $12 \mathrm{~h}$ before injection of FSH-P and every $30 \mathrm{~min}$ from 0 to $2 \mathrm{~h}$, every $2 \mathrm{~h}$ from 2 to $10 \mathrm{~h}$ and every $4 \mathrm{~h}$ from 10 to $58 \mathrm{~h}$ after injection of FSH-P. Concentrations of FSH were determined in plasma using the radioimmunoassay described by Keisler et al. (1985). The FSH standard was NIAMDD oFSH-RP-1 (AFP5679C). The sensitivity of the assay was $25 \mathrm{pg}$ per tube and intra- and interassay coefficients of variation were $9.5 \%$ and $9.1 \%$, respectively.

\section{Experiment 5}

In Expt 5, 198 mature (original group plus replacements, 3-7 years of age), nonlactating, Manchega ewes that had lambed previously in August and September received $100 \mu \mathrm{g}$ of cloprostenol in December, 1991. Ewes detected at oestrus by vasectomized rams were assigned by age and weight to one of five treatments. On day 13 , ewes received $100 \mu \mathrm{g}$ cloprostenol and one of the following treatments: (i) $2 \mathrm{ml}$ saline, i.m. ( $n=$ 22); (ii) $2 \mathrm{ml}$ propylene glycol, i.m. $(n=24)$; (iii) $10 \mathrm{mg}$ FSH-P in $2 \mathrm{ml}$ propylene glycol, i.m. $(n=25)$; (iv) $10 \mathrm{mg}$ FSH-P in Downloaded from Bioscientifica.com at 04/26/2023 01:35:12PM 
$2 \mathrm{ml}$ saline and $2 \mathrm{ml}$ of propylene glycol, given at separate sites, i.m. ( $(n=25)$; or (v) $10 \mathrm{mg}$ of FSH-P in $2 \mathrm{ml}$ of saline, i.m. $(n=$ 24). Laparoscopic observations of ovaries were performed 8-9 days after the second cloprostenol injection and number of corpora lutea determined.

\section{Statistical analysis}

No analysis was required for Expt 1 , because all ewes except one had single ovulations. In Expt 2, data for number of corpora lutea were examined for differences due to year, dose of FSH-P at day 1 , dose of FSH-P at day 13 and their interactions by analysis of variance for a completely randomized design, using general linear models procedures (SAS, 1985). Differences among subgroups were evaluated by the method of least significant difference when main effects and interactions were significant (Steel and Torrie, 1980). Data of Expt 3 were analysed in the same manner for differences due to vehicle and day of treatment with FSH-P. In Expt 5, data were analysed as a completely randomized design with differences among treatments determined by the method of least significant differences. A square root transformation of the data was used for Expts 2,3 and 5 to achieve a normal distribution and homogeneity of variance.

Data for concentrations of FSH in Expt 4 were analysed as a split plot over time with treatment as the main plot and time as the subplot. Polynomial regressions over time were also fitted for each experimental unit and a multivariate analysis of variance was performed on the regression coefficients (Allen et al., 1983). Area under the curve for FSH, peak concentration of $\mathrm{FSH}$, interval from injection of highest concentration of $\mathrm{FSH}$, and disappearance (interval from peak to basal concentration of FSH) were analysed as a completely randomized design, using analysis of variance.

\section{Results}

\section{Experiments 1 and 2}

The number of corpora lutea did not differ among treatment groups in Expt 1; of the 98 ewes studied, only one ewe in the control group had two corpora lutea. In Expt 2, there were significant effects of year $(P=0.01)$ and of dose of FSH-P on day $1(P<0.01)$, dose of FSH-P on day $13(P<0.01)$ and the interaction between FSH-P on day 1 and FSH-P on day 13 $(P<0.01$; Table 1$)$. The effects of FSH-P diluted in propylene glycol were of two types. First, a significant increase in the number of corpora lutea was found in ewes treated with $10 \mathrm{mg}$ FSH-P only on day 13, to a mean of 5.5 , compared with a control value of 1.5. Second, although the dose of $5 \mathrm{mg}$ FSH-P had no effect on either day 1 or day 13 when given alone, the $5 \mathrm{mg}$ dose on day 1 significantly reduced the number of corpora lutea formed in response to $10 \mathrm{mg} \mathrm{FSH}-\mathrm{P}$ on day $13(P<0.01$; Table 1). The difference in ovulation rate between years was due to higher ovulation rates in year 2 in the ewes that received FSH-P on day 13. The number of corpora lutea observed in ewes receiving $10 \mathrm{mg} \mathrm{FSH}-\mathrm{P}$ on day 13 was highly variable, with a range from one to seven corpora lutea in the first year and one to 12 corpora lutea in the second year.
Table 1. Numbers of corpora lutea (mean and SD) observed at laparoscopy 7-12 days after synchronized oestrus ${ }^{a}$ in ewes treated with FSH-P diluted in propylene glycol

\begin{tabular}{|c|c|c|c|c|c|c|c|}
\hline \multirow{2}{*}{\multicolumn{2}{|c|}{ FSH-P (mg) }} & \multicolumn{6}{|c|}{ Expt $2^{b}$} \\
\hline & & \multicolumn{3}{|c|}{ Year 1} & \multicolumn{3}{|c|}{ Year 2} \\
\hline \multicolumn{2}{|c|}{ Day $^{b}$} & & & & & & \\
\hline I & 13 & $n$ & Mean & SD & $n$ & Mean & SD \\
\hline 0 & 0 & 8 & 1.4 & 0.5 & 14 & 1.5 & 0.5 \\
\hline 0 & 5 & 8 & 1.3 & 0.5 & 13 & 2.1 & 1.2 \\
\hline 0 & 10 & 8 & 4.1 & 2.2 & 15 & 6.3 & 3.8 \\
\hline 5 & 0 & 7 & 1.3 & 0.5 & 14 & 1.4 & 0.5 \\
\hline 5 & 5 & 9 & 1.4 & 0.5 & 17 & 1.8 & 1.0 \\
\hline 5 & 10 & 8 & 1.9 & 0.9 & 16 & 2.9 & 2.0 \\
\hline
\end{tabular}

${ }^{\mathrm{a}} 100 \mu \mathrm{g}$ of cloprostenol were injected on day 13 after oestrus to synchronize the oestrus at which ovulation rate was measured.

'Day $0=$ day of oestrus.

Table 2. Numbers of corpora lutea (mean and SD), 7-12 days after synchronized oestrus ${ }^{\mathrm{a}}$ in ewes treated with $10 \mathrm{mg}$ of FSH.P diluted in propylene glycol or saline

\begin{tabular}{|c|c|c|c|c|}
\hline \multirow[b]{2}{*}{ Vehicle } & \multirow{2}{*}{$\begin{array}{c}\text { Day of FSH } \\
\text { administration }\end{array}$} & \multirow[b]{2}{*}{$n$} & \multicolumn{2}{|c|}{$\begin{array}{c}\text { Number of } \\
\text { corpora lutea }\end{array}$} \\
\hline & & & Mean & SD \\
\hline Saline & 12 & 15 & 1.3 & 0.8 \\
\hline Propylene glycol & 12 & 14 & 1.4 & 1.2 \\
\hline Saline & 13 & 15 & 2.5 & 2.5 \\
\hline Propylene glycol & 13 & 15 & 4.7 & 3.6 \\
\hline
\end{tabular}

${ }^{\mathrm{a}} 100 \mu \mathrm{g}$ of cloprostenol were injected on day 13 after oestrus. Day $0=$ day of oestrus.

\section{Experiment 3}

In Expt 3, there were significant effects of both diluent $(P=$ $0.05)$ and day of treatment $(P<0.01)$ and there was a trend towards an interaction $(P=0.08)$. Again, $10 \mathrm{mg}$ FSH-P diluted in propylene glycol increased the number of corpora lutea when it was administered on day 13 (4.7), compared with the same dose diluted in saline $(2.5 ; P<0.05)$. However, ovulation rate did not differ between diluents when FSH-P was injected on day 12, $24 \mathrm{~h}$ before cloprostenol (1.3, Table 2).

\section{Experiment 4}

In Expt 4, concentrations of FSH in plasma increased rapidly after i.m. injection of FSH-P diluted in saline, reaching a maximum value $3.6 \pm 0.5 \mathrm{~h}$ after injection (Fig. 1). With propylene glycol as diluent, the time of the maximum observed value was $2.7 \pm 0.7 \mathrm{~h}$. The only significant difference was between routes of injection $(P<0.01)$; FSH reached a maximum value $7.6 \pm 0.7 \mathrm{~h}$ after s.c. injection in propylene glycol. There were Downloaded from Bioscientifica.com at 04/26/2023 01:35:12PM 


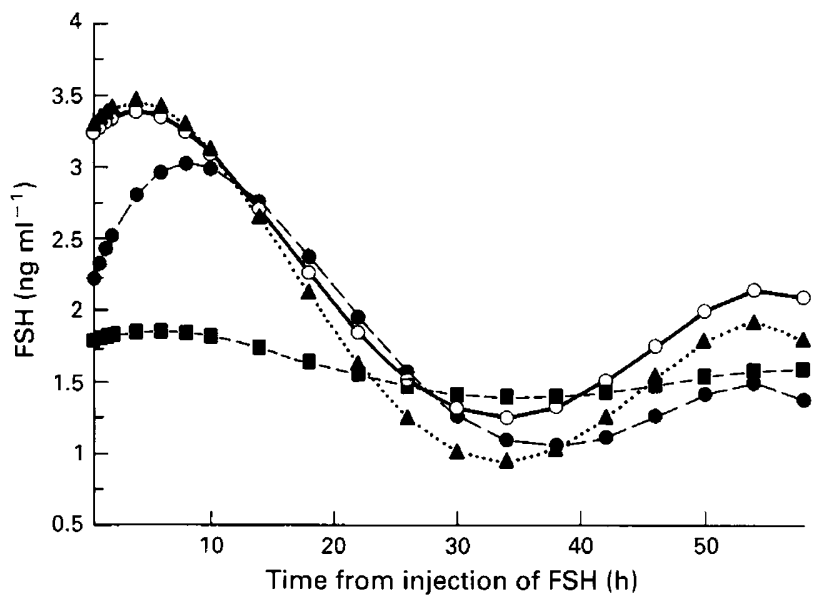

Fig. 1. Concentrations of FSH in jugular plasma after injection of propylene glycol, i.m. (ם) FSH-P diluted in propylene glycol and administered i.m. (O) or s.c. $(\mathbf{O})$ or FSH-P diluted in saline, i.m. ( $\mathbf{\Delta})$. Error mean square for reduced model was 0.61 .

no differences in the interval from the highest value until concentrations of FSH returned to basal values, which was $15.8 \pm 2.2 \mathrm{~h}$ for saline and $16.9 \pm 3.0 \mathrm{~h}$ for propylene glycol in ewes injected i.m. Thus total periods of increased FSH were $19.3 \pm 2.3 \mathrm{~h}$ and $19.6 \pm 3.1 \mathrm{~h}$, respectively. No differences were found among FSH-treated ewes in either the pretreatment value, the area under the curve for $\mathrm{FSH}$ or the maximum value. In the control group, concentrations of FSH remained at basal values throughout the sampling period.

\section{Experiment 5}

Because of the lack of difference in patterns of plasma FSH in Expt 4, Expt 5 was conducted to determine whether propylene glycol potentiated the effect of FSH-P independently from serving as a diluent. The mean numbers of corpora lutea did not differ for ewes receiving saline, propylene glycol or FSH-P in saline (Table 3). Treatment with propylene glycol and FSH-P in saline at separate sites increased ovulation rate $(P<0.05)$ compared with either saline or propylene glycol, given alone, but not compared with FSH-P in saline. Ovulation rate was greater $(P<0.05)$ in ewes treated with FSH-P in propylene glycol than in ewes treated with FSH-P in saline and propylene glycol at a separate site.

\section{Discussion}

An increase in the mean number of corpora lutea was induced by a single injection of $10 \mathrm{mg}$ FSH-P in propylene glycol on day 13 of the oestrous cycle, when cloprostenol was injected on day 13 to induce oestrus. The response was highly variable; throughout these studies, the variance consistently increased with the mean. When the same dose of FSH-P was diluted in saline, it was ineffective in both Expts 1 and 3. If the data of Expt 1 only had been available, age of the animals (Inskeep et al., 1967) and synchronization method might have been assumed to be the reasons FSH-P in saline was ineffective. Armstrong and Evans (1983) reported that FSH induced superovulation in
Table 3. Numbers of corpora lutea (mean and SD), 8-9 days after synchronized oestrus ${ }^{\mathrm{a}}$ in ewes treated with FSH-P, vehicle or both

\begin{tabular}{llll} 
Treatment & $n$ & Mean & SD \\
\hline Saline & 22 & 1.4 & 0.7 \\
Propylene glycol & 24 & 1.2 & 0.5 \\
FSH-P in propylene glycol & 25 & 6.4 & 6.1 \\
FSH-P in saline + propylene glycol & 25 & 4.0 & 5.1 \\
FSH-P in saline & 24 & 2.3 & 2.6
\end{tabular}

${ }^{\mathrm{a}} 100 \mu \mathrm{g}$ of cloprostenol were injected on day 13 after oestrus. Day $0=$ day of oestrus.

postpubertal ewe lambs synchronized with a 12-day treatment with progesterone, but it was less effective in such lambs synchronized with prostaglandin $\mathrm{F}_{2 \alpha}$. As patterns of FSH in plasma were nearly identical between the two vehicles in the study reported here, it is difficult to explain why FSH-P in saline was ineffective.

The effects of propylene glycol on the rate of absorption or degradation could be useful in the utilization of FSH, which is rapidly cleared from the blood (Akbar et al., 1974); the half-life was estimated at about $110 \mathrm{~min}$ in sheep (Fry et al., 1987). Absorption of FSH-P diluted in propylene glycol was slower when it was administered s.c. rather than i.m., but there was no difference between i.m. injections in propylene glycol or saline. The interval for removal after $\mathrm{FSH}$ reached a maximum was about $16 \mathrm{~h}$ for i.m. injection in saline, in agreement with data for cows (Demoustier et al., 1988). Intervals for removal were similar for FSH diluted in propylene glycol and injected i.m. or s.c. Propylene glycol is a slow releasing vehicle for steroid hormones, increasing the period of higher concentrations of progesterone after i.m. injection to 5 days, compared with 3 days for olive oil (A. Lopez-Sebastian, unpublished).

Propylene glycol may have exerted its effects through an alteration in the biochemical nature of FSH, which could have retained biological activity even though it was not detectable by the radioimmunoassay (Peckham et al., 1973). Propylene glycol must serve as the diluent to produce its full effect. When FSH-P was given in saline and propylene glycol was given at a separate site, ovulation rate was not increased to the same extent as was obtained with FSH-P in propylene glycol. Propylene glycol seemed to have some effect when given at the same time as FSH-P but not when serving as the diluent. The numbers of corpora lutea were similar in ewes receiving saline alone, propylene glycol alone, or FSH-P in saline. However, there were more corpora lutea in ewes treated with FSH-P in saline and propylene glycol at a separate site than in ewes treated with saline or propylene glycol only. Propylene glycol may have changed enzyme activity in the liver, which is the major site of clearance for FSH (Morell et al., 1971), thus increasing the half-life of the hormone.

The mean number of corpora lutea (5.5) obtained with a single injection of $10 \mathrm{mg}$ FSH-P (Expt 2) was similar to that reported for superovulatory procedures using $12 \mathrm{mg}$ FSH during 3.5 days in seven injections, $(6.7$ corpora lutea; Smith, 1984) or $15 \mathrm{mg} \mathrm{FSH}$ given in six injections over 3 days (8.4 corpora Downloaded from Bioscientifica.com at 04/26/2023 01:35:12PM 
lutea; Walker et al., 1986). In the present study, stimulation with FSH-P before initiation of luteolysis with cloprostenol or for longer was not critical for attainment of an increase in ovulation rate. This observation is in contrast with earlier data, in which treatment with the same total dose over $48 \mathrm{~h}$ before progestogen removal (Lopez-Sebastian et al., 1990) or $48 \mathrm{~h}$ after cloprostenol (Henderson et al., 1988) was more effective than durations of 24 or $20 \mathrm{~h}$, respectively.

The fact that $5 \mathrm{mg}$ FSH-P on day I significantly reduced the ovulation rate in response to $10 \mathrm{mg}$ FSH-P on day 13 in Expt 2 is of considerable interest. In a study by Ware et al. (1988), a single injection of $5 \mathrm{mg}$ FSH-P on day 1 had no effect on the number of corpora lutea. Likewise, a single injection of $\mathrm{GnRH}$ on day 1 , which released $\mathrm{FSH}$ and $\mathrm{LH}$ for $9 \mathrm{~h}$, had no effect (Findlay and Cumming, 1976). In several studies in cattle, reviewed by Ware et al. (1988), single injections of $5-10 \mathrm{mg}$ FSH-P on day 1 gave a wide range of responses to subsequent superovulatory treatment, but sometimes a clear increase in ovulation rate was observed. However, multiple injections of $5 \mathrm{mg}$ FSH-P early in the cycle decreased ovulation rate in heifers (Lussier and Carruthers, 1989). Roche and Boland (1991) proposed that the reduced response could result from early recruitment of medium follicles that were not oestrogen-active. Ewes may differ from cows because follicular dominance is not a clear characteristic in ewes (Driancourt and Fry, 1988) and the largest follicles appear and disappear continuously in ewes (Schrick et al., 1992) as opposed to follicular waves and a single dominant follicle in cows (Savio et al., 1988).

Ewes treated with $10 \mathrm{mg}$ FSH-P in propylene glycol one day before cloprostenol (Expt 3) did not show an increase in ovulation rate compared with those treated with FSH in saline, whereas ewes treated on the day of cloprostenol treatment did show a difference due to the vehicle. Perhaps the stimulation required to support follicular growth was not maintained for long enough for the follicles in these ewes to remain responsive to the increase in $\mathrm{LH}$ that follows prostaglandin-induced luteolysis on day 13 (Deaver et al., 1986). Increased pulsatile release of $\mathrm{LH}$ is believed to be responsible for final follicular growth and ovulation (Richards, 1980). Picton and McNeilly (1991) reported that ovine follicles greater than $2.5 \mathrm{~mm}$ in diameter require support from $\mathrm{LH}$ in addition to $\mathrm{FSH}$, and Driancourt et al. (1987) concluded that atretic follicles cannot be rescued by exogenous gonadotrophin.

It is concluded that a single injection of FSH-P in propylene glycol could be used to increase ovulation rate in ewes; however, it remains difficult to predict the response to a given dose in a given ewe. Although the precise roles of FSH and LH in follicular development remain unclear, there is evidence that FSH both recruits and stimulates growth of oestrogenic follicles (Picton et al, 1990), until the size of the follicle requires LH for final maturation and a surge of gonadotrophin (either FSH or LH; Murdoch and Inskeep, 1981) for successful transformation into a corpus luteum. However, the high variability in FSH:LH ratio of commercially available batches of FSH-P is well known (Lindsell et al., 1986), and the shorter half-life of LH with respect to FSH (Akbar et al., 1974) could increase variability in the expected response to gonadotrophins.

In addition, the dose of FSH used is not the only variable to consider, because the effect of exogenous gonadotrophin is strongly modulated by intraovarian factors, so that there is not a linear relationship between gonadotrophin concentrations and ovulation rate (Driancourt et al., 1988; Fry et al., 1988). More purified preparations of FSH may be able to improve the predictability of the response of exogenous gonadotrophins on ovulation rate (Murphy et al., 1984).

The authors thank E. C. Townsend and S. Lerner for assistance with statistical analyses; M. L. Barragan and R. A. Picazo for assistance with laparoscopic observations; the NIADDK for immune reagents for the FSH radioimmunoassay; and D. Tortonese for assistance in translation of Spanish to English.

\section{References}

Akbar AM, Nett TM and Niswender GD (1974) Metabolic clearance and secretion rates of gonadotropins at different stages of the estrous cycle in ewes Endocrinology 94 1318-1324

Allen OB, Burton JH and Holt JD (1983) Analysis of repeated measurements for animal experiments using polynomial regression Journal of Animal Science $\mathbf{5 7}$ $765-770$

Armstrong DT and Evans G (1983) Factors influencing success of embryo transfer in sheep and goats Theriogenology 19 3I-43

Cahill LP, Saumande J, Ravault JP, Blanc M, Thimonier J, Mariana JC and Mauleon P (1981) Hormonal and follicular relationship in ewes of high and low ovulation rates Journal of Reproduction and Fertility 62 141-150

Casida LE, Warwick EJ and Meyer RA (1944) Survival of multiple pregnancies induced in the ewe following treatment with pituitary gonadotropins Joumal of Animal Science $322-28$

Deanesly R (1939) Modification of the effectiveness of gonadotrophic extracts Journal of Endocrinology 1 307-322

Deaver DR, Stilley NJ, Dailey RA, Inskeep EK and Lewis PE (1986) Concentrations of ovarian and pituitary hormones following prostaglandin $F_{2 a}$ induced luteal regression in ewes varies with day of the estrous cycle at treatment Journal of Animal Science 62 422-427

Demoustier MM, Beckers JF, Van der Zwalmen P, Closset J, Gillard JL and Ectors F (1988) Determination of porcine plasma follitropin levels during superovulation treatment in cows Theriogenology 30 379-386

Driancourt MA and Fry RC (1988) Differentiation of ovulatory follicles in sheep Joumal of Animal Science 66 (Supplement 2) 9-20

Driancourt MA, Fry RC and Cahill LP (1987) Follicular growth and regression during the 8 days after hypophysectomy in sheep Journal of Reproduction and Fertility 79 635-644

Driancourt MA, Philipon P, Locatelli A, Jacques E and Webb R (1988) Are differences in FSH concentrations involved in the control of ovulation rate in Romanov and Ile-de-France ewes Journal of Reproduction and Fertility 83 509-516

Fevold HL, Hisaw FL and Greep R (1936) Augmentation of the gonad-stimulating action of pituitary extracts by inorganic substances, particularly copper salts American Journal of Physiology 117 68-74

Findlay JK and Cumming IA (1976) Increase in ovulation rate in sheep following administration of an LHRH analogue Biology of Reproduction 15 115-117

Fry RC, Cahill LP, Cummins JT, Bindon BM, Piper LR and Clarke IJ (1987) The half-life of follicle-stimulating hormone in ovary-intact and ovariectomized Booroola and control Merino ewes Journal of Reproduction and Fertility 81 611-615

Fry RC, Clarke IJ, Cummins JR, Bindon BM, Piper LR and Cahill LP (1988) Induction of ovulation in chronically hypophysectomized Booroola ewes Journal of Reproduction and Fertility $82711-715$

Henderson KM, Savage LC, Ellen RL, Ball K and McNeilly KP (1988) Consequences of increasing or decreasing plasma FSH concentrations during the preovulatory period in Romney ewes Journal of Reproduction and Fertility $\mathbf{8 4}$ 187-196

Inskeep EK, Barr AL and Cunningham CJ (1967) Repeatability of prolificacy in sheep Journal of Animal Science 26 458-461

Keisler DH, Inskeep EK and Dailey RA (1985) Roles of pattern of secretion of luteinizing hormone and the ovary in attainment of puberty in ewe lambs Domestic Animal Endocrinology 2 123-132

Lahlou-Kassi A, Schams P and Glatzel P (1984) Plasma gonadotrophin concentrations during the oestrous cycle and after ovariectomy in two breeds of Downloaded from Bioscientifica.com at 04/26/2023 01:35:12PM 
sheep with low and high fecundity Joumal of Reproduction and Fertility $\mathbf{7 0}$ 165-173

L'Hermite M, Niswender GD, Reichert LE and Midgley AP (1972) Serum folliclestimulating hormone in sheep as measured by radioimmunoassay Biology of Reproduction 6 325-332

Lindsell CE, Rajkumar K, Manning AW, Emery SK, Mapletoft RJ and Murphy BD (1986) Variability in FSH/LH ratios among batches of commercially available gonadotropins Theriogenology 25167 (Abstract)

Lopez-Sebastian A, Cognie Y, Cocero MJ, de la Fuente J and Poulin N (1990) Effect of season and duration of FSH treatment on embryo production in sheep Theriogenology 34 175-180

Lussier JG and Carruthers TD (1989) Endocrine and superovulatory responses in heifers pretreated with FSH or bovine follicular fluid Theriogenology 31 779-794

McShan WH and Meyer RK (1945) Augmentation of sheep pituitary gonadotropin by insoluble metallic hydroxides Proceedings of the Society for Experimental Biology and Medicine 59 239-242

Morell AG, Gregoriadis G and Scheinberg IH (1971) The role of sialic acid in determining the survival of glycoproteins in the circulation journal of Biological Chemistry 246 1461-1467

Murdoch MJ and Inskeep EK (1981) Factors affecting luteinization of sheep and rabbit ovarian follicles: follicular contents and luteinizing hormone Biology of Reproduction 24 1171-1181

Murphy BD, Mapletoft RJ, Manns J and Humphrey WD (1984) Variability in gonadotropin preparations as a factor in the superovulatory response Theriogenology 21 117-125

Peckham WD, Yamaji T, Dierschke DJ and Knobil E (1973) Gonadal function and the biological and physicochemical properties of follicle stimulating hormone Endocrinology 92 1660-1666

Picton HM and McNeilly AS (1991) Effect of basal and pulsatile LH release on FSHstimulated follicle growth in ewes chronically treated with gonadotrophinreleasing hormone agonist joumal of Endocrinology 128 449-456
Picton HM, Tsonis CG and McNeilly AS (1990) FSH causes a time dependent stimulation of preovulatory follicle growth in the absence of pulsatile $\mathrm{LH}$ secretion in ewes chronically treated with gonadotrophin releasing hormone agonist Joumal of Endocrinology 126 297-307

Rexroad CE and Powell AM (1991) FSH injections and intrauterine insemination in protocols for superovulation of ewes Joumal of Animal Science $69246-251$

Richards IS (1980) Maturation of ovarian follicles: actions and interactions of pituitary and ovarian hormones on follicular cell differentiation Physiological Reviews 60 51-89

Roche JF and Boland MP (1991) Turnover of dominant follicles in cattle of different reproductive states Theriogenology 35 81-90

SAS (1985) Statistical Analysis System (SAS) User's guide. SAS Institute Inc, Cary, NC

Savio JD, Kerman L, Boland MP and Roche JF (1988) Pattern of growth of dominant follicles during the oestrous cycle in heifers Journal of Reproduction and Fertility $83663-671$

Schrick FN, Surface RA, Pritchard JY, Townsend EC, Dailey RA and Inskeep EK (1992) Monitoring of follicular and embryonic development in ewes by transrectal ultrasonography Joumal of Animal Science 70 (Supplement 1) 273 (Abstract)

Smith CL (1984) Dose effect of follicle stimulating hormone for superovulation of crossbred Targhee ewes Theriogenology 21262

Steel RGD and Torrie JH (1980) Principles and Procedures of Statistics (2nd Edn) McGraw-Hill, New York

Walker SK, Smith DH and Seamark RF (1986) Timing of multiple ovulation in the ewe after treatment with FSH or PMSG with or without GnRH journal of Reproduction and Fertility 77 135-142

Ware CB, Northey DL, Boland MP and First NL (1988) Early cycle FSH-P priming as a prelude to superovulating gonadotropin administration in ewes and heifers Animal Reproduction Science 16 97-105 